Croux, F., De Donder, L., Claes, B., Vandevelde, S., \& Brosens, D. (Accepted). Peer support as a bridge for participation in prison activities and services: A qualitative study with foreign national prisoners. Criminology \& Criminal Justice.

\title{
Peer support as a bridge for participation in prison activities and services: A qualitative study with foreign national prisoners
}

\begin{abstract}
This paper investigates the role of informal peer support as a bridge for participation by foreign national prisoners in prison activities (e.g., education, work, sports activities, library) and services (e.g., psychologist, doctor). A total of 51 individual interviews, following an appreciative inquiry perspective, were conducted with foreign nationals in four prisons in Flanders (Belgium). In terms of leading foreign nationals to prison activities and services, the findings reveal four types of informal peer support: informational support, instrumental support, emotional support, and social companionship. Moreover, during participation in these prison activities and services, three types of informal peer support emerged:

informational support, instrumental support, and social companionship. Peer support seems to be a 'form of survival' for foreign nationals to overcome barriers experienced in accessing prison activities and services and difficulties during participation in such prison activities and services.
\end{abstract}

\section{Keywords}

Foreign nationals, informal peer support, social support, participation, prison activities and services

\section{Introduction}


This paper focuses on the role of informal peer support as a bridge for participation in prison activities and services by foreign national prisoners. Prison activities relate to group activities and include sports activities, library, cultural activities, prison yard, (vocational) education, work and worship. Services include individual services such as psychosocial services, psychologist, judicial welfare work and doctor.

Foreign national prisoners are prisoners who do not hold the nationality of the detaining country (Atabay, 2009). Their representation in Belgian prisons has increased sharply in the last several decades. While in $1980,21.4 \%(n=1,212)$ of the Belgian prison population consisted of foreign nationals (Beyens et al., 1993), this increased to $44.6 \%$ $(n=4,601)$ by 2018 (Croux et al., 2019a) ${ }^{1}$, which is remarkably higher than the European average (21.2\% in 2016) (Aebi et al., 2017). In general, several explanations may contribute to this higher presence in prisons, such as a higher likelihood of detection and apprehension, a limited awareness of, and unequal access to, legal support (Atabay, 2009), or a selective and differential judicial treatment at the sentencing level (Beyens, 2007). Despite their high number, "it is startling how little we have until recently known about foreign nationals in prison, and the challenges they experience and represent." (Ugelvik, 2015: 108). This is also true regarding knowledge of the role informal peer support plays in foreign nationals' participation in prison activities and services. Based on research among the general population that has cited the importance of social support for participation (e.g., in leisure/physical activities (Mendonça et al., 2014; Sasidharan et al., 2006) and education (Wang and Eccles, 2012)), we can assume that informal peer support can play a role regarding participation in prison activities and services. This study aims to better understand the role of informal peer support as a bridge for participation by foreign nationals, by (1) studying the types of informal peer support leading foreign nationals to prison activities and services, and (2) exploring the types of informal peer support provided or received during 
such participation.

\section{Foreign nationals' participation in prison activities and services}

Participation in prison activities and services is a right of all prisoners, including foreign nationals. This has been confirmed in international and European instruments, such as the United Nations Standard Minimum Rules for the Treatment of Prisoners (the Nelson Mandela Rules) (United Nations, 2015) and the European Prison Rules (Council of Europe, 2020). In particular for foreign nationals in European prisons, the Committee of Ministers stipulates that prison governments should provide equal access to a balanced set of prison activities and services by undertaking specific actions to respond to the difficulties foreign nationals experience. Despite foreign nationals' equal rights regarding participation as national prisoners (Council of Europe, 2012), they have fewer participation opportunities (Brosens, 2019; Van Kalmthout et al., 2007) in terms of education (Westrheim and Manger, 2014), vocational training (Atabay, 2009), prison work, and medical care (Van Kalmthout et al., 2007).

Foreign nationals experience several difficulties in participating in prison activities and services (Van Kalmthout et al., 2007). Research has shown that it is not nationality but rather residential status and language proficiency that influence foreign nationals' participation opportunities in prison (Brosens et al., 2020). A prisoner's mastering of the Dutch language clarifies more about participation than nationality. Language and nationality are not synonymous. Belgian prisons house prisoners with Belgian nationality that may have difficulties speaking Dutch as well as foreign nationals who have a command of the Dutch language (Brosens et al., 2016). However, speaking the official language of the prison does not mean that prisoners are able to read and write it. A study in five Nordic countries found that, on average, $25 \%$ to $33 \%$ of the general prison population experienced writing and 
reading difficulties (Eikeland, 2009). Research among foreign nationals has demonstrated that they are often better in speaking the official language of the prison than in writing it. Those who have some command of the official language experience fewer difficulties in reading simple and short texts compared to longer texts. Foreign nationals may not only experience writing and reading difficulties in the prison's official language, some are unable to read and write in their mother tongue (Westrheim and Manger, 2013). As a result, foreign nationals frequently miss out on information about the activity offer (Croux et al., 2019b; Westrheim and Manger, 2014). Moreover, prisoners sign up for prison activities often through report notes, which can often be problematic as many foreign nationals cannot write in the national language of the prison (Snacken, 2007). In addition, being unable to speak the official prison language hinders foreign nationals' participation, as a good understanding of this language is often required in order to participate (Croux et al., 2019b). The exception is sports activities, as prisoners seem to overcome language-related difficulties with non-verbal communication (Van Kalmthout et al., 2007). In addition, waiting lists (Van Kalmthout et al., 2007;

Westrheim and Manger, 2014), staff shortages and an overlap in prison activities impede foreign nationals' participation (Croux et al., 2019b).

\section{Peer support}

Peer support "encompasses a wide range of roles or schemes by which people offer direct practical help and support to other prisoners, either in a paid or voluntary capacity" (Edgar et al., 2011: 14). Peer support may have several benefits for the peer deliverers (e.g., improving self-esteem) (Heidemann et al., 2016), recipients (e.g., reducing stress) (Jaffe, 2012), and the prison (e.g., reducing prison officers' workloads) (Edgar et al., 2011). According to the literature, peer support can be classified into: (1) formally organised peer-based interventions, and (2) informal peer support (Brosens, 2019; Jaffe, 2012). 
First, the 'Foreign National Orderlies' is an example of a formally organised peer-based intervention for foreign national prisoners in England and Wales. Trained and paid prisoners are responsible for the cultural and linguistic integration of newly-arrived foreign nationals by identifying needs (e.g., psychological problems, language barriers), visiting, informing, referring them to prison staff if necessary, and composing lists of fellow prisoners who want to serve as interpreters (Bhui, 2004; Martínez-Gómez, 2014). In Belgian prisons, formally organised peer-based interventions are rarely available (Brosens and De Donder, 2017).

Second, peer support can take place informally, without being formally supported or organised (Brosens, 2019; Jaffe, 2012). Informational support from compatriots is important for newly-arrived foreign nationals, as the information provided to them upon induction is often inadequate (Martynowicz, 2016). Moreover, during participation in prison activities, peers provide information to one another (Martynowicz, 2016; Van Kalmthout et al., 2007), or encourage foreign nationals to participate (Croux et al., 2019b). Further, prisoners help one another by serving as interpreters to bridge the language barrier (Martínez-Gómez, 2014). Sometimes, they even learn languages from each other (Croux et al., 2019b). Matos (2016) described examples of foreign national women who were provided clothing or food by fellow prisoners.

A conceptual analysis of peer support revealed three attributes: emotional support, informational support, and appraisal support (Dennis, 2003). Moreover, a conceptual analysis of social support also considered instrumental support to be among the most commonly used attributes (Langford et al., 1997). Some scholars also referred to social companionship as an attribute of social support (Cohen and Wills, 1985; Ryan et al., 2008). Table 1 provides an overview of the attributes of support.

Table 1. Overview of the attributes of support

\section{Attributes of support Definition}




\begin{tabular}{|c|c|}
\hline Emotional support & The provision of empathy, care, trust, and love (House, 1981). \\
\hline Informational support & $\begin{array}{l}\text { Providing information to cope with environmental or personal } \\
\text { problems (House, 1981). } \\
\text { Exchange of relevant information or advice for the benefit of } \\
\text { particular needs (Berkman et al., 2000). }\end{array}$ \\
\hline Appraisal support & $\begin{array}{l}\text { Giving information that is important for self-evaluation (House, } \\
\text { 1981). } \\
\text { Providing suitable feedback relevant for making decisions } \\
\text { (Berkman et al., 2000). }\end{array}$ \\
\hline Instrumental support & $\begin{array}{l}\text { Providing financial and material resources and services (Cohen } \\
\text { and Wills, 1985). }\end{array}$ \\
\hline Social companionship & $\begin{array}{l}\text { Spending time with others in recreational and leisure activities } \\
\text { (Cohen and Wills, 1985; Ryan et al., 2008). }\end{array}$ \\
\hline
\end{tabular}

\section{Purpose of study}

To the best of our knowledge, little to no research has explored the role of informal peer support as a bridge to participation by foreign nationals. This paper addresses the following research questions:

(1) What types of informal peer support are provided or received to lead foreign national prisoners to prison activities and services?

(2) What types of informal peer support do foreign national prisoners provide or receive during participation in prison activities and services?

\section{Data and methods}

This paper uses qualitative data on foreign nationals from four prisons in Flanders (Belgium), from a larger project called 'Foreigners' Involvement and Participation in Prison' (FIP² project). Ethical clearance was obtained from the Ethics Commission in Human Sciences of the Vrije Universiteit Brussel (reference number ECHW_134), and prison access was granted by the national Directorate General for Penitentiary Institutions. Fourteen of 19 prisons in Flanders and Brussels were interested in participating. Four were selected by a steering group (i.e., co-authors, activity coordinator working in prison, and members of the justice 
department) based on four criteria: heterogeneity of remand and sentencing prisons, prison population size, a medium or large number of prison activities for foreign nationals (based on earlier research within the FIP²-project, Brosens et al., 2017), and diversity in terms of regimes and departments. Table 2 provides more information on the characteristics of the participating prisons.

Table 2. Prisons' characteristics

\begin{tabular}{|c|c|c|c|c|c|c|c|c|c|c|c|c|c|}
\hline \multirow[t]{2}{*}{$\begin{array}{c}\text { Participating } \\
\text { prisons }\end{array}$} & \multicolumn{2}{|c|}{ Prison } & \multicolumn{3}{|c|}{ Regime } & \multicolumn{2}{|c|}{ Department } & \multicolumn{3}{|c|}{$\begin{array}{c}\text { Prison } \\
\text { population } \\
\text { size }\end{array}$} & \multicolumn{3}{|c|}{$\begin{array}{c}\text { Number of } \\
\text { prison activities } \\
\text { for foreign } \\
\text { nationals }\end{array}$} \\
\hline & 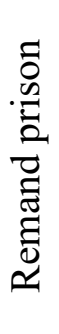 & 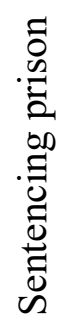 & $\begin{array}{l}\text { D } \\
0 \\
0 \\
0\end{array}$ & ڤี & $\stackrel{x}{\Sigma}$ & $\frac{0}{\sum^{\pi}}$ & 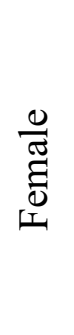 & 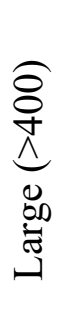 & 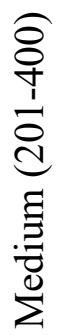 & 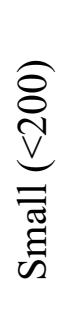 & 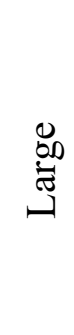 & 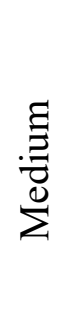 & 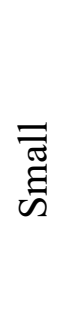 \\
\hline Prison 1 & $\mathrm{X}$ & $X$ & $\mathrm{X}$ & & & $X$ & $X$ & & $X$ & & & $X$ & \\
\hline Prison 2 & $\mathrm{X}$ & & $\mathrm{X}$ & & & $\mathrm{X}$ & & & & $\mathrm{X}$ & $\mathrm{X}$ & & \\
\hline Prison 3 & $\mathrm{X}$ & $X$ & & & $\mathrm{X}$ & $\mathrm{X}$ & & & & $\mathrm{X}$ & & $\mathrm{X}$ & \\
\hline Prison 4 & & $\mathrm{X}$ & $\mathrm{X}$ & & & $\mathrm{X}$ & & & $\mathrm{X}$ & & $\mathrm{X}$ & & \\
\hline
\end{tabular}

From the four prisons, 53 participants were interviewed by the first author, fifth author, and two master's students. Only 51 interviews were used, as two respondents declared dualnationality, one of which was Belgian. The participants were recruited by prison staff (e.g., activity coordinators, prison officers) through a recruitment letter according to specified sampling criteria: diverse nationalities, spoken languages, age, length of prison stay, (non)participants in prison activities, and sentencing title. The participants included both foreign nationals with and without residence status. Table 3 provides information on the participants' characteristics.

\section{Table 3. Participants' characteristics}




\begin{tabular}{|c|c|c|c|c|c|}
\hline Participants & Prison 1 & Prison 2 & Prison 3 & Prison 4 & Total \\
\hline Number interviewed & 12 & 14 & 13 & 12 & 51 \\
\hline \multicolumn{6}{|l|}{ Nationalities } \\
\hline European ${ }^{1}$ & 4 & 6 & 3 & 1 & 14 \\
\hline Non-European & 7 & 7 & 9 & 10 & 33 \\
\hline Dual nationality EU \& Non-EU & 1 & 1 & 1 & 0 & 3 \\
\hline Dual nationality EU \& EU & 0 & 0 & 0 & 1 & 1 \\
\hline \multicolumn{6}{|l|}{ Gender } \\
\hline Male & 9 & 14 & 13 & 12 & 48 \\
\hline Female & 3 & 0 & 0 & 0 & 3 \\
\hline Mean age (years) & 33.08 & 35.57 & 28.69 & 35.33 & 33.18 \\
\hline (range) & $(20-49)$ & $(20-47)$ & $(20-38)$ & $(24-51)$ & $(20-51)$ \\
\hline \multicolumn{6}{|l|}{ First time in prison ${ }^{2}$} \\
\hline Yes & 10 & 12 & 8 & 8 & 38 \\
\hline No & 2 & 1 & 5 & 4 & 12 \\
\hline \multicolumn{6}{|l|}{ Interpreter present } \\
\hline Yes & 3 & 8 & 7 & 1 & 19 \\
\hline No & 9 & 6 & 6 & 11 & 32 \\
\hline \multicolumn{6}{|l|}{ Speaking the Dutch language } \\
\hline Yes & 4 & 3 & 3 & 4 & 14 \\
\hline No & 8 & 11 & 10 & 8 & 37 \\
\hline
\end{tabular}

${ }^{1}$ Belonging to one of the 27 member countries of the European Union.

${ }^{2}$ For one participant this was unclear, as it was not retrieved during the interview.

The interview scheme was semi-structured and covered three themes: (1) experiences and needs regarding participation, (2) social contact with, and support from, activity organisers, prisoners, relatives, and prison officers, and (3) reintegration and future perspectives. This study focuses on the role of informal peer support related to participation by foreign nationals, as there were no formally organised peer-based interventions available in the participating prisons.

Traditional prison studies often take a problem-oriented perspective, looking for the problems and flaws in prison practices (Liebling et al., 2001). Likewise, past research has used a problem-focused perspective on foreign national prisoners (see e.g., Banks, 2011; Warr, 2016). However, there is growing interest in integrating strengths-based approaches in several disciplines (Vandevelde et al., 2017). In light of this, appreciative inquiry has been used, which "is an attempt to generate a collective image of a new and better future by exploring the best of 
what is and has been" (Bushe, 1999: 62) and in which 'stories of the worst' are framed next to 'stories of the best' (Carter, 2006). Appreciative inquiry has already been applied in prison (e.g., Liebling et al., 2001) and probation research (e.g., Robinson et al., 2012). Appreciative inquiry is not only suitable for conducting research with foreign nationals, but it also aligns well with peer support, as both start from individuals' strengths. In this study, appreciative inquiry was used to frame our interview questions, for instance: 'What do you think is the best activity in which you have already participated in prison?' or 'If you have one wish for a prison activity that you would like to do, what would it be?'

The interviews were conducted in March and April of 2018, and lasted between 31 and 138 minutes $(M=72.56$ minutes). Before the interview, the interviewer discussed the informed consent, which all participants signed. Interviews in Dutch, French, English, or Turkish were conducted by the interviewers $(n=32)$. Nineteen interviews were conducted using interpreters from an official translation agency, except for one interview in which a prison officer was used, as no official interpreter was available in the respondents' language at the time of the interview. The interviews took place in separate rooms (e.g., classrooms, offices), but always out of earshot and the physical presence of prison staff and prisoners.

The interviews were audio-recorded and transcribed verbatim. The audio recording failed during two interviews, which were summarized in detail after the interview. A combination of deductive and inductive thematic coding was performed (Fereday and MuirCochrane, 2006) by using MAXQDA 2018. Since appreciative inquiry was used to frame the interview questions and not as an analytical strategy, the interviews were analysed deductively based on the theory-based knowledge of the attributes of support, with inductive sub-labels within the deductive labels (e.g., deductive label: informational support; inductive sub-label: information about prison activities and services). Furthermore, the inductive analysis included a distinction between informal peer support responsible for leading foreign nationals to 
participation and peer support during participation. Some scholars have noted the difficulty of distinguishing between different attributes of support (e.g., Berkman et al., 2000; House, 1981). Discussions with the co-authors were held if any doubt arose about the categorisation of the results according to the attributes of support. Nonetheless, it is possible that other scholars would categorise some of the results differently.

\section{Findings}

Participants felt that a considerable amount of informal peer support took place in prison: "Normally, almost half of the prisoners are like that [providing support]. Everyone likes to help each other" (R8, non-European, male). Some participants even felt that they had received more support from prisoners than from prison staff, and that they could only rely on peers: "If we don't do it, who else will do it?" (R6, dual nationality (non-)European, male). Providing informal peer support was mainly associated with positive feelings. Most peer deliverers were happy to do this, got satisfaction out of it, and felt good when they offered peer support. The interviews showed that informal peer support played a role regarding participation, both in terms of leading to prison activities and services and during participation in such prison activities and services.

\section{Types of informal peer support leading foreign nationals to prison activities and services}

Different types of informal peer support led foreign nationals to prison activities and services: informational support, instrumental support, emotional support, and social companionship.

Informational support. Two types of informational support took place: (1) information about prison activities and services, and (2) advice to participate in prison activities and services. Participants talked about different information channels to announce prison activities and 
services, involving both written (i.e., flyers, brochures, posters) and verbal channels (i.e., prison staff). Although they knew that these information channels existed, they lacked information when they did not understand the language in which the prison activities and services were announced, which was usually Dutch. Therefore, fellow prisoners were important sources of information about prison activities and services:

I asked them [prisoners] what activities were available and people gave information ... because there is no explanation. In here, I ask for English papers but I never get my language. Only Dutch papers, but I don't speak Dutch; so, you never understand what activities are in here (R13, non-European, male).

Informational support was important for newly-arrived foreign nationals. The peer deliverers consisted of cell mates, people who spoke the same language, compatriots, and people who had been in prison longer:

When I came here [in prison], there was someone in my cell [who informed me about the yard], and that's the system here. From the moment you come into the system, everything [information] goes automatically through other people [prisoners] (R25, non-European, male).

The informational support concerned information on the availability, enrolment, and frequency of prison activities. Participation experiences were also shared, such as mastering Dutch is a requirement for participation, the activity is only available in Dutch, or it is not possible to shower after sports participation. Participants took providing informational support for granted, as fellow prisoners had done the same when they had arrived in prison.

The informational support sometimes went even further in advising peers (often cell mates) to participate in prison activities and services by suggesting that this was a good way 
to spend one's days, was useful for taking in fresh air, enabled a better understanding of prison life, and was good for the prisoners: "It was someone [cell mate] who had obtained several diplomas, for example in language and computers. I did learn a lot from him and he also motivated me to take all those lessons" (R35, non-European, male).

Because of this informational support, several participants enrolled and eventually participated. In a few cases, informational support had the opposite effect. Sometimes, peers shared negative experiences that made respondents decide not to participate, such as information that prison activities were only in Dutch, which rendered them inaccessible for many participants. Others heard the negative experiences but nevertheless participated because they wanted to experience it for themselves.

Instrumental support. Three types of instrumental support were found: (1) facilitating access to prison activities and services, (2) learning languages informally, and (3) providing or receiving material support. First, peers facilitated access to prison activities and services. Owing to language-related difficulties, peers translated the activity folder for each other, which was not always available in an understandable language. This support was often delivered by Belgian cell mates or foreign national cell mates who had mastered the Dutch language. They also relied on peers who could write or read Dutch for writing or reading report notes to enrol in prison activities and services, as several foreign nationals could not write or read in the national language. This help was requested since report notes written in foreign languages had been answered in Dutch, or would not be read by prison staff. One respondent was tired of his dependence, and decided to learn Dutch: "When I was staying [in another prison], my friends [prisoners] always wrote my report notes for me. So, I said, 'I want to learn how to write the alphabet first;' that's why I chose the Dutch language course" (R45, non-European, male). Furthermore, peers who were already participating facilitated 
access for others by asking prison staff to put them on the waiting list, or making it possible for them to have a conversation with this person.

Second, in addition to learning languages through formal education, several respondents learned each other's languages informally. This support led a participant to partake in prison activities. He went to the library to borrow books to formulate English exercises for his cell mate. Even after changing cells, he continued to do so by going to the yard to give exercises to his former cell mate.

Third, to deal with waiting lists, newly-arrived foreign nationals were provided with material support (e.g., books) in anticipation of participation:

There [in the library], you must wait before you can go. Especially when you're new. There are many prisoners; so, you really must wait, but I do have books from the library that I can read through friends [prisoners] (R35, non-European, male).

The inaccessibility of, and need for, material resources (e.g., cigarettes, nail clippers) led participants to prison activities. As newcomers did not (yet) have access to prison work due to participation barriers, or they lacked the financial resources to meet their needs, they attended prison activities so they could trade things with peers. In this way, they had access to, and could meet their need for, material resources:

The police have taken everything; so, I don't have money now. [...]. I had to ask a friend [prisoner] to get me a nail clipper $[\ldots]$. So, the library not only serves to get a book but also serves as a tool for [sharing] that kind of stuff (R39, dual nationality (non-)European, male).

Although considerable material support was reported, this is officially not allowed. Therefore, the participants said they carried it out secretly and out of the prison officers' sight. 
This was experienced as frustrating and inhumane, as they often experience unequal access to (financial) resources in prison to meet their needs, and therefore depend on others. They wished for more freedom and autonomy to organise their own affairs.

Overall, providing instrumental support was considered a rewarding experience, as several participants enjoyed it, and it was associated with positive feelings. Some even wanted to provide it more often. However, not everyone described it as rewarding. Some felt that fellow prisoners were taking advantage of them.

Emotional support. One participant described a situation in which he had provided emotional support in leading a compatriot to the psychologist. This compatriot had felt completely lost because his father had died, and he had relationship problems. The peer deliverer felt sorry for him, and escorted him to the psychologist: "I helped him, I took his hand and took him to the psychologist” (R2, European, male). He provided this support due to concerns about a potential suicide.

Social companionship. Also, social companionship directed foreign nationals to prison activities. Several participants were motivated to participate to spend (more) time with peers: "[I'm going to the yard] to communicate with other people [prisoners]. You must talk to somebody. If you're 24 hours in your cell, you'll become crazy” (R21, European, male). Participation was perceived as a good way to spend time with people they knew or to meet new people: "You're training a bit [on the yard]; then another [prisoner] comes and asks if he can join and then it goes like: "Where are you from?" And that's how [you get to know others]" (R51, European, male). Often, they knew peers who participated in prison activities. While some participants were going to prison activities alone, several were teaming up with peers (often cell mates): "I did have a good contact with him [his cell mate]. [...] We did 
everything together regarding activities, food, watching TV, or going outside together, and exercising together" (R35, non-European, male). Having someone going with them was appreciated. Otherwise, participation was considered less fun: "Sometimes, other people are not joining, or [I have] nobody to work with - that's not so much fun" (R25, non-European, male).

\section{Types of informal peer support during foreign nationals' participation in prison activities}

\section{and services}

Peer support was not only important in leading foreign nationals to participation, but also different types of informal peer support emerged during participation: informational support, instrumental support, and social companionship.

Informational support. Two types of informational support took place: (1) information on how to perform prison activities, and (2) advice on participating in prison activities and services. During participation, informational support on how to perform prison activities was provided by prisoners who also participated in prison activities. This was important for firsttime participants because no or scant information was provided by prison staff:

I didn't know what to do, how to work. No one explained it to us [prisoners]. [...] There were only prisoners who were working, but there were no prison officers who came to explain what to do. [...] We were with six at one table and the other prisoners explained it to me: those who had worked here longer, who were a bit older, and saw that I was new (R47, dual European nationality, male). 
Informational support in terms of advice was not only relevant in leading foreign nationals to participation, but advice to go to other prison activities and services also took place during participation:

[We do] heavy work in the kitchen and [there is a prisoner] who has back problems. I already told him several times: "Man, go to the doctor on Thursday. He is a doctor from outside prison. You shouldn't be afraid [to lose your work in the kitchen]" (R41, European, male).

A few respondents also described downsides of providing informational support. Peer recipients sometimes laughed behind the peer provider's back, or ignored them after they had received the support. Nevertheless, some participants wanted to provide more informational support because they had enjoyed it.

Instrumental support. Instrumental support also took place during participation: (1) facilitating access to prison activities and services, (2) interpretation, (3) supporting or organising prison activities, and (4) providing or receiving material support. Facilitating access to prison activities and services occurred during participation in the yard. Peer deliverers who could write or read Dutch wrote or read report notes for foreign nationals who were unable to do this.

Foreign nationals also relied on peers for interpretation during participation. Some participants had only mastered their native language, while others had mastered multiple languages. Although positive comments were made about prison staff who had tried to speak other languages, there was not always a common language with the participants. Besides, most prison activities and services took place in Dutch. Therefore, fellow prisoners who had a common language with the peer recipient were called upon by prison staff or the foreign 
nationals themselves for interpretation. One participant often experienced difficulty finding someone to interpret and therefore decided to learn Dutch:

I was at the doctor's once and I wanted to ask him to do a scan, but he didn't understand me. I couldn't tell what kind of illness I had. Of course, it wasn't easy to look for someone [prisoner] to interpret every time, which is why I want to learn Dutch (R23, non-European, male).

Some participants took a more active role by supporting or organising prison activities for prisoners. Besides, some wished to support or organise (more) prison activities for prisoners, as they had certain expertise that could be called upon. One respondent wanted to teach cricket (as there was no one in prison who could teach it). Another participant wanted to offer a vocational training course in English or Polish. However, those participants felt this was impossible at the time, or that prison officers would not be receptive to it.

In addition, due to a lack of material resources provided by the prison, material support relevant during participation was available as well. As a football was not always available in the yard, the prisoners bought one themselves. This gave them the impression that the prison authorities had shirked their responsibilities. Since prison services were not always available in an understandable language, another participant borrowed a book from the library with pictures of the human body, and gave it to another prisoner who did not speak Dutch so he could use it during his appointment with the doctor.

Social companionship. Spending time with peers during prison activities was appreciated: "Sport is the best thing because ... we're together, we're playing together" (R7, nonEuropean, male). Several participants described the prison activities as a means for them to meet and communicate: "[The library] is a bit of a meeting place ... where you can have 
contact with other people [prisoners], and where we can meet... We see friends there and then we can talk for a while" (R16, European, male). Some participants even indicated that, due to social companionship in sports activities, friendships had developed.

Different respondents described the prison environment as cosmopolitan. The prisoners' nationality or religion did not seem to be important for social companionship. However, for prisoners who spoke only their native language, linguistic ability seemed to have an influence:

I don't know the language [of the prisoners in the gym]; so it's hard to talk to them. Outside [at the yard], I can have some contact with my Albanian compatriots, because they can speak my own language, but not with the others (R27, non-European, male).

Social companionship was often associated with positive feelings like being more relaxed, to help take one's mind off things, and make time go by faster: "We played a pingpong game with friends; so that's fun. When you're doing something, you forget you're in prison" (R50, non-European, male). However, social companionship was not always a positive experience. Some respondents indicated that because of fellow prisoners, they had stopped participating, or that tempers could flare during participation: "When I play [pingpong] against other nationalities [...], they get angry and start screaming; so I just let them play together" (R36, European, male). Several participants stated that the time they could spend with peers in prison activities was limited, as it was possible only when they were out of their cell. Sometimes, this was limited to people from the same section. Several participants wished for more social companionship: "You can't really communicate with other prisoners there [in the library]; so being able to spend some more time there would be good" (R39, dual nationality (non-)European, male). This wish was related not only to 
formally organised prison activities, but also to informal occupations (e.g., watching movies, playing cards, praying together in the cell, playing sports games in the section), and was often linked with the need for more open prison regimes:

When we [prisoners] get back from prison work, they [prison officers] should let us talk to one another for one hour with the cell doors open; so, we can go to others' cells, have coffee, watch a movie, or play cards together (R47, dual European nationality, male).

\section{Discussion}

This study aimed to explore informal peer support as a bridge to participation by foreign nationals by: (1) identifying the types of informal peer support that lead foreign nationals to prison activities and services, and (2) exploring the types of informal peer support provided or received during such participation. Overall, this research provides evidence that different types of informal peer support promote participation.

Regarding the first research question, the study shows that four types of informal peer support lead foreign nationals to participation: (1) informational support, (2) instrumental support, (3) emotional support, and (4) social companionship. We could argue that informal peer support leads to more participation among foreign nationals. Since prisons are often not adapted to foreign nationals' needs, informal peer support takes place to overcome inaccessibility of prison activities and services. In particular, informational and instrumental peer support take place to overcome organisational barriers in accessing prison activities and services owing to language-related problems, a lack of information, and waiting lists. Some of those organisational barriers are more pronounced for foreign nationals, such as a lack of information and the language barrier. In correspondence with previous research (Martynowicz, 2016) this study shows that, to overcome a lack of information about the available prison activities and services, fellow prisoners provide informational support. In addition, our research 
shows that informational support is particularly relevant at the beginning of detention for newcomers, which corresponds to earlier studies (Brosens, 2019; Martynowicz, 2016). Furthermore, this study reveals that instrumental support helps overcome language problems in accessing prison activities and services - for instance, by translating the activity leaflet that is not available in an understandable language or by reading or writing report notes to enrol, as many foreign nationals cannot write in the local language (Snacken, 2007). Also, the inaccessibility of, and need for, material resources in prison lead foreign nationals to participation. Foreign nationals often receive little or no financial support from their family and friends (Atabay, 2009). Finally, the findings suggest that emotional support and social companionship also help direct foreign nationals to prison activities and services.

In response to the second research question, the interviews showed that three types of informal peer support took place during participation: (1) informational support, (2) instrumental support, and (3) social companionship. This study showed that, once foreign nationals have access to prison activities and services, they still experience some participation difficulties. Informal peer support took place to deal with the difficulties foreign nationals experience during participation, such as language barriers and staff shortages (Croux et al., 2019b). In particular, informational and instrumental peer support are provided or received during participation to overcome difficulties that are more pronounced for foreign nationals, such as a lack of information and the language problem. This study found that informational support takes place while performing prison activities. Previous studies have shown that prison activities are unique places and moments for foreign nationals to be able to share information (Martynowicz, 2016; Van Kalmthout et al., 2007). In addition, instrumental support was a common type of peer support for overcoming language problems experienced during participation - for instance, by interpreting for each other during participation - as those prison activities and services are not always available in an understandable language. However, some 
scholars have noted the undesirability of this support, given the confidential and sensitive nature of certain information in prison activities and services (Atabay, 2009; Ugelvik, 2015). Although foreign nationals expressed the wish to support or organise prison activities for fellow prisoners, past research has shown that foreigners are often excluded from active participation in prison (Brosens, 2019), as they cannot take up such roles. In addition, since prisons do not meet their needs in terms of material resources, material support took place during participation. Finally, social companionship was found to be appreciated. As foreign nationals receive fewer visitors, participation in prison is a way for them to socialize (Van Kalmthout et al., 2007).

The results support the notion that, instead of remaining in a helpless situation, foreign nationals become active agents (Martynowicz, 2016) searching for ways, by means of informal peer support, to deal with the restricted access to prison activities and services, and to anticipate the difficulties experienced during participation (e.g., lack of information, language barrier). On the one hand, this can be considered to be positive, owing to the beneficial effects related to peer support (e.g., Edgar et al., 2011; Heidemann et al., 2016; Jaffe, 2012). On the other hand, the fact that foreign nationals rely on informal peer support seems to indicate that prisons are failing to recognize and anticipate their needs - for instance, in terms of social contact, material resources, language, and information about, and during, prison activities and services. "Their need to rely on each other for information and support raises serious questions about how prisons are discharging their duty of care toward them" (Martynowicz, 2016: 346). Some of the needs not being met by prisons are more pronounced for some foreign nationals, such as the language barrier and a lack of information. Prisons today are multicultural spaces, but prison services are still organised in a monocultural manner (Westrheim and Manger, 2014) - meaning that they do not consider foreign nationals' specific needs, but rather focus on the needs of the general prison population. We might ask ourselves whether the 'forms of support' that foreign nationals provide or receive to deal with this restricted and unadapted prison environment are 
not rather 'forms of survival', since they rely on fellow prisoners' strengths to 'survive' in such a prison environment.

\section{Limitations and recommendations for future research}

Five limitations and recommendations for future research can be formulated. A first recommendation relates to studying types of informal peer support that do not have a link with participation. Related to the second research question, it should be noted that, during participation, other types of informal peer support took place. For instance, emotional peer support was provided or received during participation in the yard. Also, during participation in the yard, several foreign nationals revealed that they shared information on lawyers, decisions in criminal law procedures, or the ins and outs of prison. However, these findings were excluded from this study, as those types of informal peer support did not serve as a bridge to other prison activities and services, or did not facilitate participation in the prison activity or service itself. Follow-up research can explore the role of informal peer support during foreign nationals' imprisonment more generally.

Second, as this research did not consider the influence of the diversity of the different participating prisons and foreign nationals, follow-up research can study whether differences in prisons (e.g., in terms of prison population size, prison regime) are relevant to informal peer support and how informal peer support may differ between foreign nationals (given their diversity in terms of language proficiency, right of residence, future perspectives, etc.).

Third, further research could explore the role of informal peer support in relation to foreign nationals' participation by using other research designs, and investigate the role of other social support actors. Research on this topic outside prison has used quantitative research designs (see e.g., Mendonça et al., 2014; Sasidharan et al., 2006; Wang and Eccles, 2012). Since this is the first study on this topic in a prison context, further research could explore the role of 
informal peer support in relation to foreign nationals' participation by using quantitative research methods. Additionally, longitudinal research is important for understanding how social support evolves over time (Langford et al., 1997). As this study demonstrates that informal peer support promotes participation at the beginning of detention for newcomers, it would be interesting to study how this evolves during imprisonment. In addition, in contrast to previous research outside prison, which investigated the relation between different sources of social support (e.g., peers, family) and participation (Sasidharan et al., 2006; Wang and Eccles, 2012), this study focused solely on peers. Follow-up research could explore the role of social support provided by different actors (e.g., activity organisers, prison officers, prison management, lawyers, family) in relation to foreign nationals' participation, since these different social support actors may have different influences on participation (Sasidharan et al., 2006; Wang and Eccles, 2012).

Fourth, informal peer support arose to overcome some participation difficulties - such as the language barrier and a lack of information - that are more pronounced in, but not limited to, a large group of foreign nationals. Being unable to speak, read or write the official language of the prison appears to have an important influence. We could assume that many of these research findings are also applicable to foreign-speaking prisoners with a Belgian nationality. Further research could investigate the extent to which informal peer support, in relation to participation in prison activities and services, is specific or more pronounced for foreign national prisoners.

Finally, a limitation and recommendation for future research relates to (official) interpreters. During one interview, a prison officer acted as interpreter. Although we recognize the power dynamics that take place during interpreted interviews (see e.g., Sanderson et al., 2013) - certainly with a prison officer interpreting in this case - the interviewer still did not feel that this had a negative influence on the respondent's narrative. Prior to the interview, the 
respondent was briefed and asked for permission to involve the prison officer as interpreter. Since the respondent had no objections and had a good relationship with the prison officer, the research team exceptionally decided to agree to this. However, in future research, we would choose to work only with official interpreters, since the prison officer himself made additions to the respondent's answers or indicated what he thought the answer meant. The parts of the interview in which the prison officer had an influence on the respondent's narrative were not analysed. Nevertheless, in any interview where an (official) interpreter is used, it is important to bear in mind the influence that interpreters have on the validity of the data. To improve the trustworthiness of the findings, independent translators can validate the translations (Squires, 2009). However, due to financial constraints, this was not possible in this research.

\section{Implications for prison practice}

This study has three implications for prison practice. First, since many foreign nationals cannot write in the official prison language (Snacken, 2007), prison practice might consider non-linguistic ways to enrol for prison activities and services by using pictograms and images. Second, prison practice can try to address the barriers foreign nationals face in accessing prison activities and services, and the difficulties they experience during participation, by building upon their strengths, talents, and expertise. For instance, as activity folders are often hard to understand, multilingual foreign nationals can translate them into several languages. Multilingual foreign nationals can also help activity organisers by interpreting during prison activities and services, or they can organise prison activities and services in foreign languages. Third, this study can inspire prison practice to facilitate more opportunities for peer support for foreign nationals. More opportunities for informal peer support can be promoted by providing a room or study materials to informally learn languages from one another, or by leaving the cell open to provide opportunities for social companionship. 
Although considerable informal peer support occurs, it would be valuable to explore formally-organised peer-based interventions (Devilly et al., 2005), as these are rarely available in Belgian prisons (Brosens and De Donder, 2017) for foreign nationals who wish to provide more peer support - for example, by means of peer mentoring (see Buck, 2018) or insider or listener schemes (see Edgar et al., 2011).

\section{Acknowledgments}

We thank all of the participants for their participation and the prison staff for organising this study.

\section{Funding}

The author(s) disclosed receipt of the following financial support for the research, authorship, and/or publication of this article: This work was supported by the Flemish Research Foundation (FWO) [grant number G.0269.17N].

\section{Notes}

1. These data from October 24, 2018, were taken from the national SIDIS Suite database on the Belgian prison population.

\section{References}

Aebi MF, Tiago MM, Berger-Kolopp L, et al. (2017) Space I-Council of Europe Annual Penal Statistics: Prison Populations. Survey 2016. Strasbourg: Council of Europe. Atabay T (2009) Handbook on Prisoners with Special Needs. Vienna: United Nations Office on Drugs and Crime. 
Banks J (2011) Foreign National Prisoners in the UK: Explanations and Implications. The Howard Journal of Criminal Justice 50(2): 184-198.

Berkman LF, Glass T, Brissette I, et al. (2000) From social integration to health: Durkheim in the new millennium. Social Science \& Medicine 51(6): 843-857.

Beyens K (2007). Justitie met een kleurtje. Orde van de Dag - Criminaliteit en Samenleving 40: 21-27.

Beyens K, Snacken S and Eliaerts C (1993) Barstende Muren. Overbevolkte Gevangenissen: Omvang, Oorzaken en Mogelijke Oplossingen. Antwerpen-Arnhem: Kluwer-Gouda, Interuniversitaire Reeks Criminologie en Strafwetenschappen.

Bhui HS (2004) Going the Distance. Developing Effective Policy and Practice for Work with Foreign National Prisoners. Available at:

http://www.prisonreformtrust.org.uk/Portals/0/Documents/going\%20the\%20distance\%20\%20\%20foreign\%20national\%20prisoners.pdf (accessed 7 November 2019).

Brosens D (2019) Prisoners' participation and involvement in prison life: Examining the possibilities and boundaries. European Journal of Criminology 16(4): 466-485.

Brosens D, Croux F, Claes B, et al. (2020) An organizational analysis of foreign national prisoners' participation possibilities in Flanders (Belgium). Journal of Prison Education and Reentry 6(2): 144-161.

Brosens D, Croux F, Vandevelde S, et al. (2017) Participatie van niet-Belgische gedetineerden in Vlaamse en Brusselse gevangenissen: Een helikopteroverzicht van acties en projecten. Fatik 34(156): 4-15.

Brosens D and De Donder L (2017) Peer-to-peer leren en ondersteuning: ook mogelijk in gevangenissen!? Panopticon 38(2): 142-146.

Brosens D, De Donder L, Dury S, et al. (2016) Participation in Prison Activities: An Analysis of the Determinants of Participation. European Journal on Criminal Policy and Research 22: 
$669-687$.

Buck G (2018) The core conditions of peer mentoring. Criminology \& Criminal Justice 18(2): 190-206.

Bushe GR (1999) Advances in appreciative inquiry as an organization development intervention. Organization Development Journal 17(2): 61-68.

Carter B (2006) 'One expertise among many’ — working appreciatively to make miracles instead of finding problems: Using appreciative inquiry as a way of reframing research. Journal of Research in Nursing 11(1): 48-63.

Cohen S and Wills T (1985) Stress, social support and the buffering hypothesis. Psychological Bulletin 98(2): 310-357.

Council of Europe (2012) Recommendation CM/Rec(2012)12 of the Committee of Ministers to member States concerning foreign prisoners. Available at: https://search.coe.int/cm/Pages/result_details.aspx?ObjectId=09000016805c9df0 (accessed 7 November 2019).

Council of Europe (2020) Recommendation Rec(2006)2-rev of the Committee of Ministers to member States on the European Prison Rules. Available at: https://search.coe.int/cm/Pages/result_details.aspx?ObjectID=09000016809ee581 (accessed 28 August 2020).

Croux F, Brosens D, Vandevelde S, et al. (2019b) Foreign national prisoners in Flanders (Belgium): Motivations and barriers to participation in prison programmes. European Journal on Criminal Policy and Research 25(2): 171-188.

Croux F, Brosens D, Vandevelde S, et al. (2019a) Uitdagingen in het opzetten en het uitvoeren van interviews met niet-Belgische gedetineerden. KWALON Tijdschrift voor Kwalitatief Onderzoek 24(1): 37-44.

Dennis C (2003) Peer support within a health care context: A concept analysis. International 
Journal of Nursing Studies 40(2003): 321-332.

Devilly GJ, Sorbello L, Eccleston L, et al. (2005) Prison-based peer-education schemes. Aggression and Violent Behavior 10(2): 219-240.

Edgar K, Jacobson J and Biggar K (2011) Time Well Spent: A Practical Guide to Active Citizenship and Volunteering in Prison. London: Prison Reform Trust.

Eikeland O-J (2009) Differences and similarities in the Nordic region. In: Eikeland O-J, Manger T and Asbjørnsen A (eds) Education in Nordic Prisons. Prisoners' Educational Backgrounds, Preferences and Motivation. Copenhagen: Nordic Council of Ministers, pp. 177-197.

Fereday J and Muir-Cochrane E (2006) Demonstrating rigor using thematic analysis: A hybrid approach of inductive and deductive coding and theme development. International Journal of Qualitative Methods 5(1): 80-92.

Heidemann G, Cederbaum JA, Martinez S, et al. (2016) Wounded healers: How formerly incarcerated women help themselves by helping others. Punishment \& Society 18(1): 3-26. House JS (1981) Work Stress and Social Support. Reading, Mass: Addison-Wesley. Jaffe M (2012) Peer Support and Seeking Help in Prison: A Study of the Listener Scheme in Four Prisons in England. PhD Thesis, Keele University, UK.

Langford CPH, Bowsher J, Maloney JP, et al. (1997) Social support: A conceptual analysis. Journal of Advanced Nursing 25(1): 95-100.

Liebling A, Elliott C and Arnold H (2001) Transforming the prison: Romantic optimism or appreciative realism? Criminology and Criminal Justice 1(2): 161-180.

Martínez-Gómez A (2014) Interpreting in prison settings: An international overview. Interpreting 16(2): 233-259.

Martynowicz A (2016) Not so multicultural prison: Polish prisoners in a transitional prison system. Criminology \& Criminal Justice 16(3): 337-349. 
Matos R (2016) Trajectories and identities of foreign national women: Rethinking prison through the lens of gender and citizenship. Criminology \& Criminal Justice 16(3): 350-365. Mendonça G, Cheng LA, Mélo EN, et al. (2014) Physical activity and social support in adolescents: a systematic review. Health Education Research 29(5): 822-839.

Robinson G, Priede C, Farrall S, et al. (2012) Doing 'strengths-based' research: Appreciative Inquiry in a probation setting. Criminology \& Criminal Justice 13(1): 3-20.

Ryan L, Sales R, Tilki M, et al. (2008) Social networks, social support and social capital: The Experiences of recent Polish migrants in London. Sociology 42(4): 672-690.

Sanderson T, Kumar K and Serrant-Green L (2013) “Would you Decide to Keep the Power?": Reflexivity on the Interviewer-Interpreter-Interviewee Triad in Interviews with Female Punjabi Rheumatoid Arthritis Patients. International Journal of Qualitative Methods 12(1): $511-528$

Sasidharan V, Payne L, Orsega-Smith E, et al. (2006) Older adults' physical activity participation and perceptions of wellbeing: Examining the role of social support for leisure. Managing Leisure 11(3): 164-185.

Snacken S (2007) Belgium. In: van Kalmthout AM, Hofstee-van der Meulen FBAM and Dünkel F (eds) Foreigners in European Prisons. Nijmegen: Wolf Legal Publishers, pp. 127156.

Squires A (2009) Methodological challenges in cross-language qualitative research: A research review. International Journal of Nursing Studies 46(2): 277-287. Ugelvik T (2015) The incarceration of foreigners in European prisons. In: Pickering S and Ham J (eds) The Routledge Handbook on Crime and International Migration. London and New York: Routledge, pp. 107-120.

United Nations (2015) United Nations Standard Minimum Rules for the Treatment of Prisoners (the Nelson Mandela Rules). Available at: 
https://www.unodc.org/documents/justice-and-prison-reform/GA-

RESOLUTION/E_ebook.pdf(accessed 7 November 2019).

Van Kalmthout AM, Hofstee-van der Meulen FBAM and Dünkel F (2007) Comparative overview, conclusions and recommendations. In: Van Kalmthout AM, Hofstee-van der Meulen FBAM and Dünkel F (eds) Foreigners in European Prisons. Nijmegen: Wolf Legal Publishers, pp. 7-88.

Vandevelde S, Vander Laenen F, Van Damme L, et al. (2017) Dilemmas in applying strengths-based approaches in working with offenders with mental illness: A critical multidisciplinary review. Aggression and Violent Behavior 32: 71-79.

Wang MT and Eccles JS (2012) Social support matters: Longitudinal effects of social support on three dimensions of school engagement from middle to high school. Child Development 83(3): 877-895.

Warr J (2016) The deprivation of certitude, legitimacy and hope: Foreign national prisoners and the pains of imprisonment. Criminology \& Criminal Justice 16(3): 301-318.

Westrheim K and Manger T (2013) Educational background, preferences and needs. A qualitative study of prisoners from Iraq, Poland, Russia, Serbia and Somalia. Bergen: County Governor of Hordaland.

Westrheim K and Manger T (2014) Iraqi prisoners in Norway: Educational background, participation, preferences and barriers to education. Journal of Prison Education and Reentry 1(1): 6-19. 